\title{
Recent additions of warmwater fish species to Chesapeake Bay
}

Aimee D. Halvorson

Virginia Institute of Marine Science

Follow this and additional works at: https://scholarworks.wm.edu/vimsarticles

Part of the Aquaculture and Fisheries Commons, and the Marine Biology Commons

\section{Recommended Citation}

Halvorson, Aimee D., Recent additions of warmwater fish species to Chesapeake Bay (2007).

Northeastern Naturalist, 14(4), 651-656.

DOI: 10.1656/1092-6194(2007)14[651:RAOWFS]2.0.CO;2

This Article is brought to you for free and open access by the Virginia Institute of Marine Science at W\&M ScholarWorks. It has been accepted for inclusion in VIMS Articles by an authorized administrator of W\&M ScholarWorks. For more information, please contact scholarworks@wm.edu. 


\title{
Recent Additions of Warmwater Fish Species to Chesapeake Bay \\ Aimee D. Halvorson"
}

\begin{abstract}
During September 2004 and June 2005, the Virginia Institute of Marine Science (VIMS) Juvenile Fish and Blue Crab Trawl Survey collected specimens of three warmwater fish species uncommon to Chesapeake Bay. Captures of Trachinocephalus myops (Snakefish), Citharichthys macrops (Spotted Whiff), and Mullus auratus (Red Goatfish) are the first substantiated records for these species from Chesapeake Bay. These captures also represent extensions in the documented geographic ranges of Snakefish and Spotted Whiff. Occurrences of multiple species heretofore rarely encountered in Chesapeake Bay warrant further attention in view of concerns regarding climate change and its effect on local marine faunas.
\end{abstract}

Chesapeake Bay is the largest estuary in the United States and has "one of the most extreme annual temperature ranges known for coastal ecosystems in the world" (Murdy et al. 1997). It is located in a transitional biogeographic region (Boesch and Wright 1999), with the neighboring continental shelf serving as a mixing area for boreal, temperate, and subtropical species (Murawski 1993). The fish fauna of Chesapeake Bay has been extensively studied (Hildebrand and Schroeder 1928, Massman 1962, Murdy et al. 1997, Musick 1972); therefore, documenting unusual species occurrences in Chesapeake Bay is important because climatic changes in the nearby oceanic environment may be reflected in changes in the species mix occurring within estuarine faunal communities of this region.

The Virginia Institute of Marine Science (VIMS) Juvenile Fish and Blue Crab Trawl Survey has sampled the lower portion of the mainstem Chesapeake Bay sporadically from 1955-1988 and monthly from 1988 to present (Montane et al. 2004). The temporal and spatial coverage of this survey enables the effective monitoring of presence, distribution, and abundance of various finfishes and invertebrates throughout the Virginia portion of Chesapeake Bay. Therefore, collection within Chesapeake Bay during an 11-month period of three species (Trachinocephalus myops Forster 1801 [Snakefish], Citharichthys macrops Dresel 1885 [Spotted Whiff], and Mullus auratus Jordan and Gilbert 1882 [Red Goatfish]) that are more common to southern or oceanic/continental shelf waters is noteworthy. Fishes were captured in lower Chesapeake Bay with a 9.14-m otter trawl (38.1-mm stretched mesh body, 6.35-mm cod liner). Voucher specimens are deposited in the Ichthyological Collection, Virginia Institute of Marine Science, Gloucester Point, VA (C. macrops VIMS 11345, $M$. auratus VIMS 11347, and T. myops VIMS 11352).

A single specimen of Snakefish, measuring $83 \mathrm{~mm}$ standard length (SL), was collected on September 13, 2004 at $37^{\circ} 03.96^{\prime} \mathrm{N}, 76^{\circ} 00.19^{\prime} \mathrm{W}$, in $6.4 \mathrm{~m}$ of water near the Chesapeake Bay Bridge-Tunnel High-Rise Bridge (Fig. 1). The bottom water temperature was $25^{\circ} \mathrm{C}$, bottom salinity was $23.9 \%$, and the substrate was presumably sand. This species was not included in checklists or detailed treatments of the fishes of Chesapeake Bay and Maryland (Hildebrand and Schroeder 1928, Massman 1962, Murdy et al. 1997, Musick 1972, Truitt et al. 1929) nor was it reported in a study of the fishes of the seaside waters of Virginia's Eastern Shore (Richards and Castagna 1970). No previous records in the VIMS Juvenile Fish and Blue Crab Trawl Survey database document snakefish from Chesapeake Bay, and no specimens from Chesapeake Bay exist in the VIMS Ichthyological Collection (P. Gerdes, VIMS,Gloucester Point, VA. pers. comm.) or the US National Museum (USNM) fish collection (L. Palmer, Smithsonian Institution, Washington, DC, pers. comm.). 
Snakefish (Synodontidae) is an epibenthic species found nearly worldwide in tropical and warm temperate waters except for the eastern Pacific (Briggs 1960). In the western Atlantic, Snakefish inhabits waters from the West Indies and Brazil to the coast of South Carolina, occasionally being found as far north as Woods Hole, MA (Jordan et al. 1955). In the area from Cape Hatteras to the southern Scotian shelf, early life-history stages of Snakefish occur in continental shelf and oceanic waters (Fahay 1983), including the Gulf Stream (Gibbs 1959). Occasionally this species is washed ashore during storms (Anderson et al. 1966). In the western North Atlantic, adult and juvenile Snakefish are most frequently collected offshore: at 27-366 m between Cape Fear and Cape Hatteras, NC (Bowman et al. 2000), from 10-19 m off Georgia and South Carolina (SEAMAP-SA/SCMRD Staff 2000), 16-24 km off the coast of Georgia (Dahlberg 1975), and in 20-52 m in the Gulf of Mexico (Brooks et al. 2004). The capture, therefore, of this species within the Chesapeake Bay estuary is very unusual since elsewhere in the region both adults and juveniles are usually found on the continental shelf.

A few reported captures of this species from more northern localities exist including those in marine waters off New York (Briggs and Waldman 2002), where it is considered a rare visitor (10 or fewer reports since 1960), and off New Jersey (first record of a specimen taken in $12 \mathrm{~m}$ at $7.4 \mathrm{~km}$ offshore the New Jersey coast; Milstein and Thomas 1976), where the species is also considered only a rare visitor (Able 1992).

A 105-mm SL specimen of Spotted Whiff (Paralichthyidae), a warm-temperate species, was collected on September 13,2004 , at $37^{\circ} 03.96^{\prime} \mathrm{N}, 76^{\circ} 00.19^{\prime} \mathrm{W}$, in $6.4 \mathrm{~m}$ near the Chesapeake Bay Bridge-Tunnel High Rise Bridge (Fig. 1). Bottom water temperature and salinity were $25^{\circ} \mathrm{C}$ and $23.9 \%$, respectively, and the substrate was

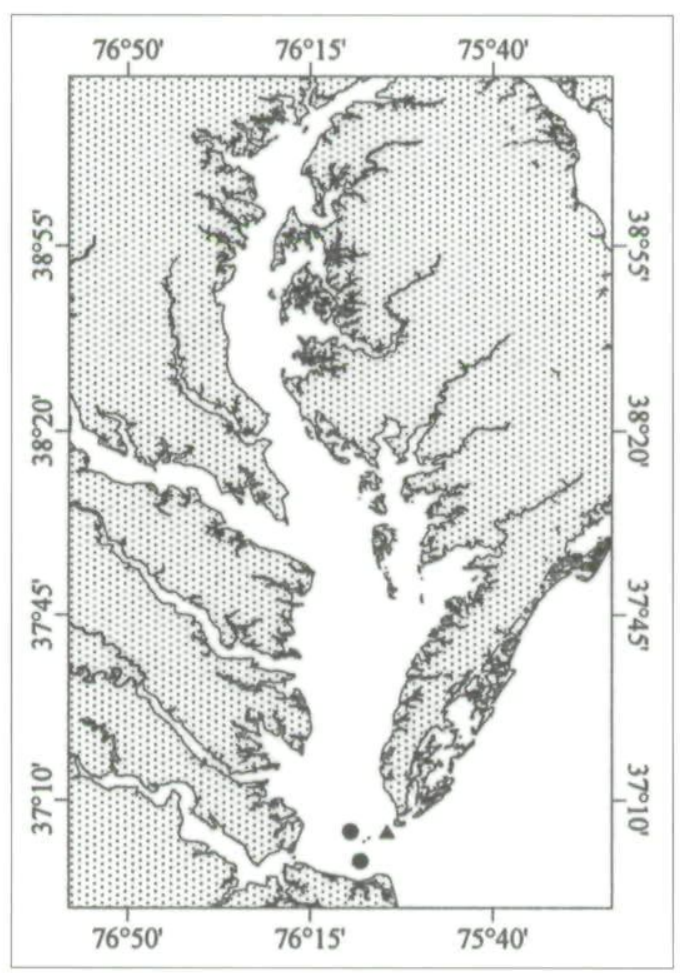

Figure 1. Map of Chesapeake Bay showing catch locations of $M$. auratus (Red Goatfish), T. myops (Snakefish), and C. macrops (Spotted Whiff). Triangle indicates the station from which Snakefish and Spotted Whiff were collected in 2004. Circles represent the stations from which Red Goatfish were collected in 2005 and 2006. 
presumably sand. Spotted Whiff was not listed in earlier studies of the fishes occurring in Chesapeake Bay (Hildebrand and Schroeder 1928, Massman 1962, Murdy et al. 1997, Musick 1972, Truitt et al. 1929) or Delaware Bay (Michels 1999) nor was it taken in the seaside waters of Virginia's Eastern Shore (Richards and Castagna 1970). Sporadic captures of Spotted Whiff were indicated from 1955-1980 in the VIMS Juvenile Fish and Blue Crab Trawl Survey database and one specimen was reported captured during the 1994 and 1996 VIMS Juvenile Bluefish Seine Survey (A. Hewitt, VIMS, Gloucester Point, VA, pers. comm.). However, no voucher specimens were saved from these studies, making it difficult to confirm these earlier captures. Neither the VIMS Ichthyological Collection (P. Gerdes, VIMS, Gloucester Point, VA, pers. comm.) nor the USNM fish collection possess any C. macrops taken from Chesapeake Bay (L. Palmer, Smithsonian Institution, Gloucester Point, VA, pers. comm.).

Elsewhere, Spotted Whiff is found along the South Atlantic and Gulf of Mexico coasts of the US (Dahlberg 1975, Jordan et al. 1955). The species is commonly collected in numerous North Carolina estuaries (Ross and Bichy 2002, Schwartz et al. 1982, Walsh et al. 1999), throughout the South Atlantic Bight (SEAMAP-SA/ SCMRD Staff 2000) and in the northwestern Gulf of Mexico (Brooks et al. 2004). The specimen of Spotted Whiff captured in 2004 represents the first substantiated record of this species from Chesapeake Bay and also documents a northern extension of the known geographic range for the species.

A 40-mm SL specimen of Red Goatfish (Mullidae), a subtropical demersal species, was caught on June 16,2005 at $37^{\circ} 03.98^{\prime} \mathrm{N}, 76^{\circ} 07.17^{\prime} \mathrm{W}$, approximately 3 nautical miles (nm) northwest of the third island of the Chesapeake Bay BridgeTunnel (Fig. 1). The bottom water temperature $(10.4 \mathrm{~m})$ was $16^{\circ} \mathrm{C}$ and the bottom salinity was $28.5 \%$. The species is reported as being a rare summer visitor to lower Chesapeake Bay (Murdy et al. 1997), and there is one unsubstantiated record of a 58$\mathrm{mm}$ FL Red Goatfish being collected by the VIMS Juvenile Fish and Blue Crab Trawl Survey in June 1989 at $3700.78 \mathrm{~N}, 7600.04^{\prime} \mathrm{W}$, approximately $3.5 \mathrm{~nm}$ southeast of the fourth island of the Chesapeake Bay Bridge-Tunnel. The 1989 specimen was not deposited in the VIMS Ichthyological Collection (P. Gerdes, VIMS, pers. comm.) or the USNM fish collection (L. Palmer, Smithsonian Institution, pers. comm.). Richards and Castagna (1970) collected one Red Goatfish (58 mm FL) from the seaside waters of Virginia's Eastern Shore in Metomkin Inlet.

Along the southeastern coast of the US, Red Goatfish has been captured off North and South Carolina, Georgia, and Florida, as well as in the Gulf of Mexico (Caldwell 1962, Dahlberg 1975). The species has not been collected from estuaries in North Carolina (Ross and Bichy 2002, Schwartz et al. 1982), Maryland (Truitt et al. 1929), or Delaware (Michels 1999). The species is reported as uncommon in waters off New York (Briggs and Waldman 2002), rare in New Jersey waters (Able 1992, 1999; Fowler 1906), and is only an adventitious visitor to Narragansett Bay, RI (Powell 2001, Tracy 1910). The Red Goatfish specimen collected in 2005 represents the first individual validating the occurrence of this species from waters within Chesapeake Bay. Interestingly enough, two additional specimens (41 and $43 \mathrm{~mm} \mathrm{SL}$ ) of Red Goatfish were collected in August 2006 at $36^{\circ} 58.38^{\prime} \mathrm{N}, 76^{\circ} 05.32^{\prime} \mathrm{W}$, approximately 1 $\mathrm{nm}$ southeast of the second island of the Chesapeake Bay Bridge-Tunnel (Fig. 1).

Range extensions and rare geographic occurrences of species warrant further attention in view of concerns regarding climate change and its effect on local marine faunas. Scientists believe the geophysical processes governing climate will create a warmer Earth that will exhibit more extreme variations (Boesch and Wright 1999) 
and different wind, precipitation, and water-circulation patterns than presently exist (Kennedy 1990). Climate warming will modify distribution patterns of marine organisms, possibly causing cold-tolerant species to retreat poleward, with warm-tolerant species expanding their ranges poleward (Kennedy 1990). Effects of rising temperatures on marine ecosystems may first be encountered in the western North Atlantic, as water temperature there is predicted to increase at a faster rate than the global average for oceans (Murawski 1993). Based on analysis of results from bottom-trawl surveys, Murawski (1993) determined that even small increases of only $1{ }^{\circ} \mathrm{C}$ in average annual water temperature contributed to statistically significant poleward range extensions for multiple fish species occurring on the continental shelf of the western North Atlantic. Parker and Dixon (1998) re-surveyed a reef community off North Carolina 15 years after an initial survey (1975-1977 and 1990-1992) and also found what they thought were multiple indications of a warming trend occurring at the reef including: 1) 29 new occurrence records for species of tropical fishes, 2) an overall increase in observances of tropical fishes, 3 ) no new occurrence records for temperate fish species, and 4) a decrease in observances of temperate fish species. Mean monthly bottom-water temperature in winter was $1-6^{\circ} \mathrm{C}$ warmer during the $1990-1992$ survey than the 1975-1977 survey (Parker and Dixon 1998). This reef study and the analysis by Murawski (1993) both indicate increasing water temperatures along the western North Atlantic US continental shelf, and the response within communities comprised of temperate and tropical species within these areas becoming more tropical centric (Parker and Dixon 1998).

Boesch and Wright (1999) predict climate change will warm the winter and transitional seasons of Chesapeake Bay, altering the species composition. Species near their southern limit may no longer survive or be prolific in Chesapeake Bay, while warm temperate species found in the Carolinas could become more common (Boesch and Wright 1999). Therefore, while collection of one individual of a species may not be statistically significant, these confirmed records for Snakefish, Spotted Whiff, and Red Goatfish during 2004, 2005, and 2006 possibly indicate the beginning of more permanent range extensions of warmwater species into Chesapeake Bay that in turn reflect changes in the surrounding marine environment. The faunal communities within Chesapeake Bay should continue to be monitored to determine the extent and permanence of increased catches of such warmwater species.

Acknowledgments. I would like to thank Dr. Thomas A. Munroe (National Systematics Laboratory, NMFS/NOAA, Smithsonian Institution) for verifying the identification of C. macrops, Paul Gerdes (VIMS) for his assistance with the VIMS Ichthyological Collection, and Lisa Palmer (Division of Fishes, National Museum of Natural History, Smithsonian Institution). Thomas Munroe reviewed earlier versions of the manuscript. Funding for the survey during September 2004 and June 2005 was provided by NOAA Chesapeake Bay Office (Project No. NA03NMF4570378) and the Virginia Marine Resource Commission Marine Recreational Fishing Advisory Board (Project No. RF05-15).

\section{Literature Cited}

Able, K.W. 1992. Checklist of New Jersey saltwater fishes. Bulletin of the New Jersey Academy of Sciences 37(1):1-11.

Able, K.W. 1999. Checklist of fishes of the Jacques Cousteau National Estuarine Research Reserve at Mullica River-Great Bay. Rutgers University, Institute of Marine and Coastal Sciences. New Brunswick, NJ. Technical Report \#99-22. 
Anderson, W.W., J.W. Gehringer, and F.H. Berry. 1966. Family Synodontidae: Lizardfishes. Pp. 30-102, In Y.H. Olsen and J.W. Atz (Eds.). Fishes of the Western North Atlantic. Memoir 1 (Part 5: Lizardfishes, Other Iniomi, Deepsea Gulpers). Bianco Luno's Printing, Copenhagen, Denmark. 647 pp.

Boesch, D.F., and L.D. Wright. 1999. Effects of climate change belong on Chesapeake Bay agenda. Bay Journal 8(10):11.

Bowman, R.E., C.E. Stillwell, W.L. Michaels, and M.D. Grosslein. 2000. Food of northwest Atlantic fishes and two common species of squid. NOAA, Northeast Fisheries Science Center, Woods Hole, MA. Technical Memorandum, NMFS-NE-155. 138 pp.

Briggs, J.C. 1960. Fishes of worldwide (circumtropical) distribution. Copeia 1960(3): $171-180$.

Briggs, P.T., and J.R.Waldman. 2002. Annotated list of fishes reported from the marine waters of New York. Northeastern Naturalist 9(1):47-80.

Brooks, R.A., S.C. Keitzer, and K.J. Sulak. 2004. Taxonomic composition and relative frequency of the benthic fish community found on natural sand banks and shoals in the northwestern Gulf of Mexico. (A synthesis of the Southeast Area Monitoring and Assessment Program's Groundfish Survey Database, 1982-2000). US Geological Survey, Coastal Ecology and Consevation Research Group, USGS-Florida Integraed Science Center, CARS, Gainesville, FL. USGS Outer Continental Shelf Studies Ecosystem Program Report USGS-SIR-2004-XXX (CEC NEGOM Program Investigation Report No. 2004-0X, October 2004); Minerals Management Service, OCS Study MMS-2004-XXXX. 47 pp.

Caldwell, M.C. 1962. Development and distribution of larval and juvenile fishes of the family Mullidae of the western North Atlantic. US Fish and Wildlife Service Fishery Bulletin 62(213):403-457.

Dahlberg, M.D. 1975. Guide to Coastal Fishes of Georgia and Nearby States. University of Georgia Press, Athens, GA. 186 pp.

Fahay, M.P. 1983. Guide to the early stages of marine fishes occurring in the Western Atlantic Ocean, Cape Hatteras to the Southern Scotian Shelf. Journal of Northwest Atlantic Fisheries Science 4:1-423.

Fowler, H.W. 1906. The fishes of New Jersey. Pp. 35-477, In Annual Report of the New Jersey State Museum (1905), Part 2. MacCrellish and Quigley, State Printers, Trenton, NJ. 477 pp.

Gibbs, R.H., Jr. 1959. A synopsis of the postlarvae of western Atlantic lizard-fishes (Synodontidae). Copeia 1959(3):232-236.

Hildebrand, S.F., and W.C. Schroeder. 1928. Fishes of Chesapeake Bay. Bulletin of the US Bureau of Fisheries 43(1):1-366.

Jordan, D.S., B.W. Evermann, and H.W. Clark. 1955. Check list of the Fishes and Fishlike Vertebrates of North and Middle America North of the Northern Boundary of Venezuela and Colombia. US Government Printing Office, Washington, DC. 670 pp.

Kennedy, V.S. 1990. Anticipated effects of climate change on estuarine and coastal fisheries. Fisheries 15(6): 16-24.

Massman, W.H. 1962. Water temperatures, salinities, and fishes collected during trawl surveys of Chesapeake Bay and York and Pamunkey Rivers, 1956-1959. Virginia Institute of Marine Science, Gloucester Point, VA. Special Scientific Report No. 27. 51 pp.

Michels, S. 1999. Finfish resources of Delaware's inland bays. P. 5, In F.W. Kutz, P. Koenings, and L. Adelhardt (Eds.). Proceedings-Delmarva Coastal Bays Conference III: Tri-State Approaches to Preserving Aquatic Resources. 12-13 Nov 1999. EPA, Narrangansett, RI, Ocean City, MD. 40 pp.

Milstein, C.B., and D.L. Thomas. 1976. Fishes new or uncommon to the New Jersey coast. Chesapeake Science 17(3):198-204. 
Montane, M.M., W.A. Lowery, and H.M. Austin. 2004. Estimating relative juvenile abundance of ecologically important finfish and invertebrates in the Virginia portion of Chesapeake Bay. Project \# NA03NMF4570378, June 2003-May 2004. Annual Report to NOAA Chesapeake Bay Office. Virginia Institute of Marine Science, Gloucester Pt., VA 23062. 106 pp.

Murawski, S.A. 1993. Climate change and marine fish distributions: Forecasting from historical analogy. Transactions of the American Fisheries Society 122(5):647-658.

Murdy, E.O., R.S. Birdsong, and J.A. Musick. 1997. Fishes of Chesapeake Bay. Smithsonian Institution Press, Washington, DC. 324 pp.

Musick, J.A. 1972. Fishes of the Chesapeake Bay and adjacent coastal plain. Pp. 175-212, In M.L. Wass (Ed.). A Checklist of the Biota of Lower Chesapeake Bay with Inclusions from the Upper Bay and the Virginian Sea. Special Scientific Report No. 65. Virginia Institute of Marine Science. Gloucester Point, VA.

Parker, R.O., Jr., and R.L. Dixon. 1998. Changes in a North Carolina reef-fish community after 15 years of intense fishing: Global-warming implications. Transactions of the American Fisheries Society 127(6):908-920.

Powell, J.C. 2001. Finfish species of Narragansett Bay and Rhode Island waters. Pp. 14-33, In P.V. August, R.W. Enser, and L.L. Gould (Eds.). Vertebrates of Rhode Island. The Biota of Rhode Island. Vol. 2. Rhode Island Natural History Survey, Kingston, RI. 84 pp.

Richards, C.E., and M. Castagna. 1970. Marine fishes of Virginia's Eastern Shore (inlet and marsh, seaside waters). Chesapeake Science 11(4):235-248.

Ross, S.W., and J. Bichy. 2002. Checklist of the fishes documented from the Zeke's Island and Masonboro Island components of the North Carolina National Estuarine Research Reserve. National Estuarine Research Reserve, Silver Spring, MD. Technical Report Series 2002: 2. $34 \mathrm{pp}$,

Schwartz, F.J., W.T. Hogarth, and M.P. Weinstein. 1982. Marine and freshwater fishes of the Cape Fear Estuary, North Carolina, and their distribution in relation to environmental factors. Brimleyana 7:17-37.

SEAMAP-SA/SCMRD Staff. 2000. Southeast Area Monitoring and Assessment ProgramSouth Atlantic 10-year trawl report: Results of trawling efforts in the coastal habitat of the South Atlantic Bight, FY 1990-1999. Atlantic States Marine Fisheries Commission, Washington, D.C. Special Report No. 71.131 pp.

Tracy, H.C. 1910. Annotated list of fishes known to inhabit the waters of Rhode Island. Rhode Island Commission of Inland Fisheries, Wakefield, RI. 40 ${ }^{\text {th }}$ Annual Report. 1910:35-176.

Truitt, R.V., B.A. Bean, and H.W. Fowler. 1929. The fishes of Maryland. State of Maryland Conservation Department, Annapolis, MD. Conservation Bulletin No. 3. 120 pp.

Walsh, H.J., D.S. Peters, and D.P. Cyrus. 1999. Habitat utilization by small flatfishes in a North Carolina estuary. Estuaries 22(3B):803-813.

'Virginia Institute of Marine Science, Department of Fisheries Science, PO Box 1346, Gloucester Point, VA 23062; aimeehal@vims.edu. 
Copyright of Northeastern Naturalist is the property of Humboldt Field Research Institute and its content may not be copied or emailed to multiple sites or posted to a listserv without the copyright holder's express written permission. However, users may print, download, or email articles for individual use. 